\title{
PENGARUH LAMA PAPARAN CUKA APEL TERHADAP PERUBAHAN DIMENSI AKRILIK HEAT CURED
}

\author{
(EFFECT OF IMMERSED TIMES OF APPLE VINEGAR ON DIMENSIONAL \\ CHANGES OF HEAT CURED ACRYLIC RESIN)
}

\author{
Diana Setya Ningsih, Sri Fitriany, Herwanda, Agnesvida Respratidina \\ Departemen Dental Material \\ Fakultas Kedokteran Gigi, Universitas Syiah Kuala \\ Jl. Tgk. Tanoh Abe, Sektor Selatan \\ Kopelma Darussalam - 23111
}

\begin{abstract}
Apple vinegar is a healthy drink which consists of fenol, acid and other components. Its composition can influence the property of heat cured acrylic. Heat cured acrylic resin is available for clinical uses denture base material. The property of acrylic resin is water absorption due to instability in dimensional denture bases. Water absorption can be affected by the type of solution and immersed time. The aim of this study was to investigate the effect of immersed times heat cured acrylic resin in apple vinegar to dimensional changes. Ten specimens for this study were prepared on disc shape with the size $50 \pm 1 \mathrm{~mm}$ diameter and $0.5 \pm 0.1 \mathrm{~mm}$ thickness. Specimens were dried in desicator at $37^{\circ} \mathrm{C}$ then recorded dimensional change of spesimen (W1) using caliper (L) and analytic balance. Specimens were immersed in apple vinegar at $37^{\circ} \mathrm{C}$ for $1,3,5$ and 7 days. Specimens were dried for 15 seconds and weight of specimens were recorded (W2). Data was analyzed by using repeated Anova and post hoc pairwaise comparisons. The result of this study showed that the immersed times of apple vinegar had significant effect on dimensional change of heat cured acrylic resin $(p<0.05)$. There were significant differences between dimensional changes after 1 day with 3, 5, 7 days $(p<0.05)$ but there was no significant difference between 5 days with 7 days $(\mathrm{p}<0.05)$. In conclusion, the immersed times and type of solutions (apple vinegar) influenced on dimensional change of heat cured acrylic resin.
\end{abstract}

Key words: heat cured acrylic resin, dimensional change, time immersed, apple vinegar

\begin{abstract}
Abstrak
Cuka apel adalah minuman kesehatan yang terdiri atas fenol, asam dan komponen lainnya. Komposisi ini dapat mempengaruhi sifat resin akrilik heat cured. Resin akrilik heat cured secara klinis dapat digunakan sebagai bahan gigi tiruan. Resin akrilik dapat menyerap air sehingga menyebabkan ketidakstabilan dimensi basis gigi tiruan. Penyerapan air dipengaruhi oleh jenis larutan dan lama perendaman. Tujuan penelitian ini adalah untuk mengetahui efek lama perendaman resin akrilik heat cured dalam cuka apel terhadap perubahan dimensi. Sepuluh spesimen penelitian berbentuk disc dengan diameter $50 \pm 1 \mathrm{~mm}$ dan ketebalan $0,5 \pm 0,1 \mathrm{~mm}$ dikeringkan dalam desikator pada temperatur $37^{\circ} \mathrm{C}$ kemudian berat awal spesimen (W1) diukur menggunakan kaliper (L) dan neraca analitik. Spesimen kemudian direndam dalam cuka apel pada $37^{\circ} \mathrm{C}$ selama $1,3,5$ dan 7 hari. Spesimen dikeringkan selama 15 detik dan berat spesimen tercatat (W2). Data dianalisis dengan menggunakan repeated Anova dan post hoc pairwaise comparisons. Hasil penelitian menunjukkan lama perendaman di dalam cuka apel dapat menyebabkan perubahan dimensi resin akrilik heat cured secara bermakna $(\mathrm{p}<0,05)$. Ada perbedaan yang bermakna antara perubahan dimensi setelah 1 hari dengan 3, 5, 7 hari $(p<0,05)$, tetapi tidak ada perbedaan yang bermakna antara 5 hari dengan 7 hari $(\mathrm{p}<0,05)$. Sebagai kesimpulan, lama perendaman dan jenis larutan (cuka apel) dapat menyebabkan perubahan dimensi pada resin akrilik heat cured.
\end{abstract}

Kata kunci: resin akrilik heat cured, perubahan dimensi, lama perendaman, cuka apel 